\title{
LEMBAR KERJA MAHASISWA BERBASIS INKUIRI TERBIMBING UNTUK MENINGKATKAN KETERAMPILAN PROSES SAINS MAHASISWA
}

\author{
Saidatun Ni'mah ${ }^{1}$
}

\section{Program Studi Pendidikan Biologi STKIP PGRI Banjarmasin saidatunnimah@stkipbjm.ac.id (081253908660)}

\begin{abstract}
ABSTRAK
Penelitian ini merupakan penelitian dan pengembangan (research and development) yang bertujuan untuk mengembangkan Lembar Kerja Mahasiswa (LKM) berbasis inkuiri terbimbing untuk meningkatkan keterampilan proses sains mahasiswa Program Studi Pendidikan Biologi STKIP PGRI Banjarmasin. Model penelitian dan pengembangan yang digunakan mengadaptasi model penelitian dan pengembangan ADDIE. Jenis penelitian adalah penelitian deskriptif dengan analisis data secara kualitatif dan kuantitatif. Subjek uji coba terdiri dari validator ahli perangkat pembelajaran, validator ahli materi, validator praktisi pengajar di lapangan, uji coba kelompok kecil dan uji coba lapangan. Hasil validasi ahli perangkat pembelajaran, ahli materi, dan praktisi pengajar di lapangan secara berturut-turut sebesar 4,00; 3,06; dan 3,80 dengan rata-rata sebesar 3,62. Hasil uji coba kelompok kecil terhadap LKM sebesar 3,36. Hasil tersebut menunjukkan bahwa secara keseluruhan produk perangkat pembelajaran yang dikembangkan termasuk kategori baik dan memenuhi kriteria kelayakan (valid dan praktis) untuk dilaksanakan dalam pembelajaran di kelas. Uji coba utama dilakukan hanya pada Kompetensi Dasar 2.1 dan 3.1. Analisis LKM yang dikerjakan mahasiswa pada pertemuan 1 sebesar 81,54 dan pertemuan 2 sebesar 81,21 sehingga termasuk dalam kategori baik. Berdasarkan hasil tersebut dapat dikatakan bahwa LKM memiliki tingkat keefektifan medium atau dengan kata lain LKM Fisiologi Tumbuhan berbasis inkuiri terbimbing telah cukup efektif diterapkan dalam pembelajaran
\end{abstract}

Kata kunci: Pembelajaran Berbasis Inkuiri Terbimbing, Lembar Kerja Mahasiswa, Keterampilan Proses Sains

\section{PENDAHULUAN}

Proses pembelajaran memegang peran penting dalam menghasilkan atau menciptakan kualitas lulusan pendidikan. Hal utama yang perlu mendapatkan perhatian lebih serius oleh stakeholder pendidikan adalah menciptakan pembelajaran yang berkualitas. Aspek-aspek yang turut berpengaruh dalam menciptakan pembelajaran yang berkualitas, antara lain: 1) dosen yang profesional dan berkualitas dengan kualifikasi sesuai Undang-Undang Guru dan Dosen; 2) penggunaan metode mengajar yang menarik dan bervariasi; 3) perilaku belajar mahasiswa yang positif; dan 4) penggunaan media pembelajaran yang tepat dalam mendukung proses belajar itu sendiri (Winarno, 2009). 
Keberhasilan suatu proses pembelajaran turut dipengaruhi oleh kegiatan perencanaan pembelajaran berupa penyusunan perangkat pembelajaran. Perencanaan pembelajaran berisi rangkaian kegiatan yang harus dilaksanakan untuk mencapai tujuan pembelajaran. Perencanaan pembelajaran dapat berfungsi sebagai pedoman dalam mendesain pembelajaran yang sesuai dengan kebutuhan.

Perangkat pembelajaran yang dihasilkan dalam sebuah perencanaan pembelajaran memiliki struktur dan peran yang berbeda-beda, namun saling terkait satu dengan yang lain dalam pelaksanaan pembelajaran. Silabus digunakan sebagai acuan dalam pengembangan rencana pelaksanaan pembelajaran (RPP) atau satuan acara perkuliahan (SAP). RPP atau SAP berperan mengarahkan kegiatan belajar pada setiap pertemuan. Bahan ajar berfungsi membantu dosen dalam mengarahkan semua aktivitasnya pada proses pembelajaran, sekaligus merupakan substansi kompetensi yang seharusnya dipelajari dan dikuasai mahasiswa (Depdiknas, 2008a). Instrumen penilaian digunakan sebagai alat untuk mengukur sejauh mana tingkat pencapaian mahasiswa sekaligus memberikan informasi bagi perbaikan proses pembelajaran (Arifin, 2009).

Kewajiban dosen untuk merencanakan, melaksanakan proses pembelajaran, menilai, dan mengevaluasi pembelajaran dalam rangka menjalankan tugas keprofesionalannya dijelaskan dalam Undang-Undang Nomor 14 Tahun 2005 Pasal 60. Kemampuan dosen dalam merencanakan pembelajaran adalah bagian dari kompetensi pedagogik dan kompetensi profesional yang harus dikuasai. Kompetensi pedagogik berhubungan dengan penguasaan dosen pada berbagai macam pendekatan, metode, pengelolaan kelas, dan evaluasi pembelajaran yang sesuai dengan karakteristik materi dan perkembangan mahasiswa. Kompetensi profesional terkait dengan keluasan wawasan akademik dan kedalaman pengetahuan dosen terhadap materi keilmuan yang ditekuninya.

Salah satu faktor yang dapat menunjang kemandirian mahasiswa dalam belajar adalah ketersediaan sumber belajar yang memadai. Buku teks merupakan salah satu sumber belajar yang dapat digunakan oleh mahasiswa untuk mencari informasi seputar materi yang tengah dipelajari. Meskipun buku teks dapat dijumpai dengan mudah oleh mahasiswa, namun keberadaannya belum sepenuhnya mampu menunjang pemahaman mahasiswa terhadap materi perkuliahan yang dipelajari (Rahmi dkk., 2014).

Fisiologi Tumbuhan adalah salah satu mata kuliah wajib bagi mahasiswa Program Studi Pendidikan Biologi STKIP PGRI Banjarmasin dan memiliki beban 3(1) sks. Mata kuliah Fisiologi Tumbuhan termasuk dalam kelompok mata kuliah keilmuan dan keterampilan (MKK). Kepmendiknas Nomor 232/U/2000 Bab I Pasal 1 (8) menyatakan bahwa mata kuliah keilmuan dan keterampilan (MKK) merupakan kelompok bahan kajian dan pelajaran yang ditujukan terutama untuk memberikan landasan penguasaan dan keterampilan tertentu.

Hasil wawancara dan pengisian angket identifikasi kebutuhan dengan dosen pengampu mata kuliah Fisiologi Tumbuhan Program Studi Pendidikan Biologi STKIP PGRI Banjarmasin, diketahui bahwa dokumen kurikulum yang dimiliki saat ini masih terbatas pada silabus dan Rencana Perkuliahan Semester (RPS) mata kuliah. Dokumen kurikulum lainnya lembar kerja mahasiswa (LKM) masih belum tersedia terutama yang berpedoman pada model pembelajaran tertentu, sehingga menjadi kendala tersendiri dalam upaya pencapaian kompetensi yang telah ditentukan. Upaya yang dilakukan dosen selama ini untuk mengatasi 
kondisi tersebut adalah dengan menerapkan metode pembelajaran melalui diskusi dan tanya jawab di kelas. Dosen memberikan tugas secara individu atau kelompok kepada mahasiswa untuk mencari informasi tentang materi Fisiologi Tumbuhan yang selanjutnya dipresentasikan di depan kelas. Pembelajaran tersebut berpeluang menciptakan pola pembelajaran yang monoton dan kurang sesuai dengan karakteristik materi serta karakteristik mahasiswa sehingga dapat berdampak pada pelaksanaan pembelajaran dan hasil pembelajaran.

Salah satu upaya untuk mengatasi permasalahan tersebut adalah dengan mengembangkan LKM yang disesuaikan dengan karakteristik materi ajar dan karakteristik mahasiswa, sehingga tidak hanya memberdayakan pengetahuan kognitif, tetapi dapat memberdayakan kompetensi yang lain seperti keterampilan proses sains dan sikap mahasiswa. LKM yang dikembangkan menuntut mahasiswa untuk berpartisipasi aktif dalam perkuliahan, mandiri, tanggungjawab, dan disiplin. Melalui penggunaan LKM diharapkan mahasiswa termotivasi untuk belajar mandiri sehingga proses pembelajaran di kelas lebih efektif dan efisien karena mahasiswa mampu memahami sendiri materi perkuliahan yang akan dipelajari.

Alternatif untuk mengatasi permasalahan adalah dengan melaksanakan dan menerapkan pembelajaran berbasis inkuiri. Permendiknas Nomor 22 Tahun 2006 menyatakan, pembelajaran Biologi diharapkan tidak hanya membelajarkan fakta, konsep, dan prinsip Biologi kepada mahasiswa, tetapi juga mengharapkan mahasiswa dapat berinkuiri ilmiah dan membangun konsep sendiri melalui penjelajahan alam sekitar. Puskur (2007) dalam Apriliyana dkk (2012) mengungkapkan hal senada, yaitu proses pembelajaran Biologi hendaknya dilaksanakan secara inkuiri ilmiah (scientic inquiry) untuk menumbuhkan kemampuan berpikir, bekerja dan bersikap ilmiah serta mengkomunikasikannya sebagai aspek penting kecakapan hidup. Tipe pembelajaran inkuiri yang dipilih adalah inkuiri terbimbing karena berdasarkan hasil penelitian dapat melibatkan peserta didik secara aktif dalam proses pembelajaran (Astuti dan Setiawan, 2013), meningkatkan pemahaman peserta didik secara aktif dalam proses kegiatan pembelajaran, sehingga konsep yang dicapai menjadi lebih baik (Kubicek, 2005), dan membantu peserta didik untuk mengintegrasikan konsep-konsep yang telah mereka ketahui sebelumnya dengan peristiwa-peristiwa yang mereka amati di laboratorium (Mustachfidoh dkk., 2013).

\section{METODE PENELITIAN}

Penelitian ini merupakan penelitian dan pengembangan (research and development). Produk yang dikembangkan berupa LKM Fisiologi Tumbuhan berbasis inkuiri terbimbing. Model pengembangan yang digunakan mengacu pada model pengembangan ADDIE terdiri atas lima tahap, yaitu: 1) Analysis (analisis); 2) Design (desain); 3) Development (pengembangan); 4) Implementation (implementasi); dan 5) Evaluation (evaluasi) (Rohman dan Amri, 2013). Teknik analisis data yang digunakan dalam penelitian dan pengembangan ini menggunakan analisis deskriptif dengan melihat aspek kevalidan, kepraktisan, dan keefektifan.

Analisis terhadap kevalidan produk dilakukan terhadap data yang diperoleh dari hasil validasi oleh validator para ahli meliputi validator ahli 
perangkat pembelajaran, validator ahli materi, dan validator praktisi pengajar di lapangan. Analisis terhadap kepraktisan produk dilakukan terhadap data yang diperoleh dari hasil uji keterbacaan terhadap LKM oleh uji coba kelompok kecil yang terdiri dari 6 orang mahasiswa Program Studi Pendidikan Biologi STKIP PGRI Banjarmasin semester VI (enam) yang telah menempuh mata kuliah Fisiologi Tumbuhan. Analisis keefektifan dilakukan terhadap data yang diperoleh dari hasil penilaian terhadap LKM yang dikembangkan. Tahap uji coba utama dilakukan pada 39 mahasiswa Program Studi Pendidikan Biologi STKIP PGRI Banjarmasin semester IV (empat).

Data hasil uji coba terbatas dan hasil uji coba utama dijadikan sebagai bahan pertimbangan untuk menentukan revisi terhadap LKM yang dihasilkan. Data skor penilaian yang diperoleh akan dianalisis secara deskriptif untuk menentukan kriteria kevalidan, kepraktisan, dan keefektifan LKM yang dikembangkan. Penentuan kriteria kelayakan dan revisi produk pengembangan mengacu pada Tabel 1.

Tabel 1. Pengambilan Keputusan Revisi Lembar Kerja Mahasiswa

\begin{tabular}{ccc}
\hline Tingkat Pencapaian & Kualifikasi & Keterangan \\
\hline $1,00-1,75$ & Tidak Baik & Revisi \\
$1,76-2,50$ & Kurang Baik & Revisi \\
$2,51-3,25$ & Cukup Baik & Tidak direvisi \\
$3,26-4,00$ & Baik & Tidak direvisi \\
\hline
\end{tabular}

Sumber: Riduwan, 2005

Data hasil LKM yang dikerjakan oleh mahasiswa agar dapat memberikan makna dalam pengambilan keputusan, maka digunakan ketetapan kriteria penilaian menurut Arikunto (1998) seperti tertera pada Tabel 2.

Tabel 2 Kriteria Penilaian LKM yang dikerjakan oleh Mahasiswa

\begin{tabular}{cc}
\hline Tingkat Pencapaian (\%) & Kualifikasi \\
\hline $0-39$ & Buruk \\
$40-55$ & Kurang \\
$56-75$ & Cukup Baik \\
$76-100$ & Baik \\
\hline
\end{tabular}

\section{HASIL DAN PEMBAHASAN}

Data pada bagian ini terdiri dari data hasil uji coba terbatas dan hasil uji coba utama terhadap LKM yang telah dikembangkan. Data uji coba terbatas diperoleh dari validasi ahli perangkat pembelajaran, validasi ahli materi, validasi praktisi pengajar di lapangan, dan uji coba kelompok kecil. Uji coba kelompok kecil dilakukan oleh 6 orang mahasiswa Pendidikan Biologi STKIP PGRI Banjarmasin yang telah menempuh mata kuliah Fisiologi Tumbuhan. Data uji coba lapangan diperoleh dari hasil uji coba kepada mahasiswa yang sedang menempuh mata kuliah Fisiologi Tumbuhan. Paparan data hasil uji coba dan hasil analisis data terhadap LKM yang dikembangkan sebagai berikut.

\section{Uji Coba Terbatas}

Uji coba terbatas terdiri dari uji validasi ahli dan uji coba kelompok kecil. Data yang diperoleh pada uji coba terbatas terdapat pada Tabel 3 dan Tabel 4. 
Tabel 3. Data Validasi Ahli terhadap LKM

\begin{tabular}{lcccccccc}
\hline \multirow{2}{*}{ Aspek Penilaian } & \multicolumn{2}{c}{ Validator 1} & \multicolumn{2}{c}{ Validator 2} & \multicolumn{2}{c}{ Validator 3} & \multirow{2}{*}{ RK } & \multirow{2}{*}{ K } \\
\cline { 2 - 6 } & $\mathrm{R}$ & $\mathrm{K}$ & $\mathrm{R}$ & $\mathrm{K}$ & $\mathrm{R}$ & $\mathrm{K}$ & & \\
\hline Kelayakan Isi & 4,00 & $\mathrm{~B}$ & 3,00 & $\mathrm{CB}$ & 3,73 & $\mathrm{~B}$ & 3,58 & $\mathrm{~B}$ \\
Kebahasaan & 4,00 & $\mathrm{~B}$ & 3,17 & $\mathrm{CB}$ & 3,67 & $\mathrm{~B}$ & 3,61 & $\mathrm{~B}$ \\
Manfaat & 4,00 & $\mathrm{~B}$ & 3,00 & $\mathrm{CB}$ & 4,00 & $\mathrm{~B}$ & 3,67 & $\mathrm{~B}$ \\
\hline \multicolumn{1}{c}{ Rata-rata } & 4,00 & $\mathrm{~B}$ & 3,06 & $\mathrm{CB}$ & 3,80 & $\mathrm{~B}$ & 3,62 & $\mathrm{~B}$ \\
\hline
\end{tabular}

$$
\begin{aligned}
& \text { Keterangan : } \mathrm{R}=\text { Rata-rata } \mathrm{B}=\text { Baik } \\
& \mathrm{K}=\text { Kualifikasi } \mathrm{CB}=\text { Cukup Baik } \\
& \text { RK = Rata-rata keseluruhan }
\end{aligned}
$$

Berdasarkan data pada Tabel 3 dapat dilihat bahwa rata-rata keseluruhan penilaian oleh ketiga validator terhadap LKM yang dikembangkan sebesar 3,62. Nilai tersebut termasuk pada kategori baik dan tidak perlu direvisi (Tabel 1). Kegiatan percobaan yang dilakukan oleh mahasiswa tertuang dalam LKM yang berbasis inkuiri terbimbing, dimana mahasiswa terlibat aktif dalam pembelajaran dan menemukan konsep-konsep melalui konstruksinya sendiri.

Tabel 4. Data Uji Coba Kelompok Kecil terhadap LKM

\begin{tabular}{lcccccccccccccccc}
\hline \multirow{1}{*}{$\begin{array}{c}\text { Aspek } \\
\text { Penilaian }\end{array}$} & \multicolumn{2}{c}{ M 1 } & $\mathrm{R}$ & $\mathrm{K}$ & $\mathrm{R}$ & $\mathrm{K}$ & $\mathrm{R}$ & $\mathrm{K}$ & $\mathrm{R}$ & $\mathrm{K}$ & $\mathrm{R}$ & $\mathrm{K}$ & $\mathrm{R}$ & $\mathrm{K}$ & & \multirow{2}{*}{$\mathrm{RK}$} \\
\hline Materi/Isi & 3,50 & $\mathrm{~B}$ & 3,25 & $\mathrm{CB}$ & 3,25 & $\mathrm{CB}$ & 3,00 & $\mathrm{CB}$ & 3,13 & $\mathrm{CB}$ & 4,00 & $\mathrm{~B}$ & 3,36 & $\mathrm{~B}$ \\
Kebahasaan & 3,20 & $\mathrm{~B}$ & 3,60 & $\mathrm{~B}$ & 3,20 & $\mathrm{CB}$ & 3,20 & $\mathrm{CB}$ & 3,20 & $\mathrm{CB}$ & 3,60 & $\mathrm{~B}$ & 3,33 & $\mathrm{~B}$ \\
Sajian & 3,43 & $\mathrm{~B}$ & 3,43 & $\mathrm{~B}$ & 3,57 & $\mathrm{~B}$ & 2,86 & $\mathrm{CB}$ & 3,13 & $\mathrm{CB}$ & 4,00 & $\mathrm{~B}$ & 3,40 & $\mathrm{~B}$ \\
\hline \multicolumn{1}{c}{ Rata-rata } & 3,38 & $\mathrm{~B}$ & 3,43 & $\mathrm{~B}$ & 3,34 & $\mathrm{~B}$ & 3,02 & $\mathrm{CB}$ & 3,15 & $\mathrm{CB}$ & 3,87 & $\mathrm{~B}$ & 3,36 & $\mathrm{~B}$ \\
\hline
\end{tabular}

$$
\begin{array}{rlll}
\text { Keterangan : } \mathrm{R} & =\text { Rata-rata } & \mathrm{M} & =\text { Mahasiswa } \\
\mathrm{K} & =\text { Kualifikasi } & \mathrm{B} & =\text { Baik } \\
\mathrm{RK} & =\text { Rata-rata keseluruhan } & \mathrm{CB} & =\text { Cukup Baik }
\end{array}
$$

Berdasarkan Tabel 4 diketahui bahwa rata-rata skor penilaian uji coba kelompok kecil (uji keterbacaan) LKM oleh mahasiswa 1 sebesar 3,38, mahasiswa 2 sebesar 3,43, mahasiswa 3 sebesar 3,34, mahasiswa 4 sebesar 3,02, mahasiswa 5 sebesar 3,15, dan mahasiswa 6 sebesar 3,87. Rata-rata penilaian oleh mahasiswa secara keseluruhan adalah 3,36. Berdasarkan tabel kriteria kelayakan (Tabel 1), nilai tersebut berada pada kisaran 3,26-4,00 sehingga termasuk pada kategori baik dan tidak perlu direvisi atau dengan kata lain, LKM yang dikembangkan termasuk praktis.

\section{Uji Coba Utama}

Uji coba utama melibatkan 39 orang mahasiswa Program Studi Pendidikan Biologi STKIP PGRI Banjarmasin yang sedang menempuh mata kuliah Fisiologi Tumbuhan. Uji coba utama dilakukan untuk mengetahui keterlaksanaan dan keefektifan perangkat yang dikembangkan. Uji coba utama dilakukan dengan melaksanakan kegiatan pembelajaran menggunakan LKM yang telah dikembangkan. Uji coba utama dilaksanakan hanya pada KD 2.1 (materi fotosintesis) dan 3.1 (materi respirasi). Data yang diperoleh dari uji coba utama terdapat pada Tabel 5 berikut. 
Tabel 5. Data Hasil Penilaian Lembar Kerja Mahasiswa (LKM) yang dikerjakan Mahasiswa

\begin{tabular}{cccc}
\hline Pertemuan ke- & Materi & Rata-Rata & Keterangan \\
\hline 1 & Fotosintesis & 81,54 & Baik \\
2 & Respirasi & 81,21 & Baik \\
\hline
\end{tabular}

Tabel 5 menunjukkan bahwa rata-rata peniaian LKM yang dikerjakan oleh mahasiswa pada pertemuan 1 (materi fotosintesis) sebesar 81,54 dan pada pertemuan 2 (materi respirasi) sebesar 81,21. Nilai tersebut menunjukkan bahwa rata-rata LKM mengalami penurunan pada pertemuan selanjutnya sebesar 0,33. Berdasarkan tabel kriteria penilaian LKM (Tabel 2), hasil LKM yang dikerjakan oleh mahasiswa pada pertemuan 1 dan pertemuan 2 termasuk dalam kategori baik (76\%-100\%).

Kegiatan percobaan yang dilakukan oleh mahasiswa tertuang dalam LKM berbasis pendekatan inkuiri terbimbing, dimana mahasiswa terlibat aktif dalam pembelajaran dan menemukan konsep-konsep melalui konstruksinya sendiri. Yonata (2009) menyatakan LKM adalah panduan bagi mahasiswa belajar mandiri untuk memahami bahan kajian yang akan dipelajari. LKM dikembangkan sebagai salah satu jenis bahan ajar yang digunakan dalam pembelajaran melalui model pembelajaran berbasis inkuiri terbimbing.

LKM yang dikembangkan untuk materi Fisiologi Tumbuhan terdiri dari beberapa komponen, yaitu judul, identitas, SK, KD, indikator, dan isi LKM. LKM yang dihasilkan berupa LKM kinerja yang digunakan mahasiswa sebagai panduan dalam melakukan kegiatan percobaan. LKM yang dihasilkan berbasis inkuiri terbimbing sehingga isi LKM ini terdiri dari merumuskan masalah, merumuskan hipotesis, alat dan bahan, dan prosedur kerja. Masing-masing isi LKM di sediakan tempat jawaban mahasiswa mempermudah mahasiswa menuliskan jawabannya.

LKM berbasis inkuiri terbimbing bertujuan untuk mengarahkan mahasiswa dalam menemukan penyelesaian dari permasalahan yang disajikan pada LKM. Melalui penyelesaian tersebut, mahasiswa menjadi mandiri dalam mengaitkan solusi permasalahan dengan konsep yang dipelajarinya. Keterlibatan mahasiswa secara langsung dalam menyelesaikan permasahan yang diberikan menyebabkan mahasiswa tidak mudah lupa terhadap materi tersebut.

Ciri khas suatu produk merupakan hal yang penting dalam perancangan LKM (Rahmi dkk, 2014). Aspek desain sangat mempengaruhi keberhasilan penggunaan LKM oleh mahasiswa. Ukuran LKM yang proporsional, halaman yang tidak terlalu padat dengan tulisan, penomeran pada subjudul dan kegiatan, serta kejelasan instruksi dalam LKM, merupakan komponen-komponen yang mempengaruhi tingkat kemudahan mahasiswa dalam menggunakan dan memahami materi dalam LKM secara mandiri (Prastowo,2011)

Prosedur percobaan yang disajikan dalam LKM ini bertujuan untuk mempermudah mahasiswa melakukan percobaan secara berurutan. Pemberian prosedur percobaan dalam LKM ini sesuai dengan pembelajaran berbasis inkuiri terbimbing, yaitu mengarahkan mahasiswa untuk menemukan atau menerapkan sendiri ide-idenya. LKM hasil pengembangan memberikan alternatif strategi pembelajaran yang inovatif, konstruktif, dan berpusat pada mahasiswa, dengan memfokuskan pada tercapainya kompetensi yang diharapkan. LKM juga menyediakan kegiatan-kegiatan yang tersusun secara sistematis sehingga dapat membantu mahasiswa untuk mengkonstruksi pengetahuan mereka mealui kegiatan pengamatan pada sumber belajar. 
LKM dapat memberi kesempatan mahasiswa untuk mencari informasi berbeda dari berbagai sumber dan menghendaki adanya kreativitas mahasiswa. LKM menuntut agar mahasiswa sebelum percobaan perlu menganalisis alat dan bahan yang tersedia sehingga dapat mengarahkan mahasiswa untuk lebih professional dalam melaksanakan kegiatan percobaan. Kegiatan percobaan yang dilakukan juga dapat mengembangkan hubungan sosial dan emosional antar mahasiswa karena pada proses penggunaan LKM dilakukan secara berkelompok, dan bahasa yang digunakan sesuai tingkat intelektual mahasiswa (Yasmi dan Erviyenni, 2016)

Tryanasari (2011) menyatakan bahwa, penggunaan LKM dalam kegiatan belajar mengajar bertujuan untuk: 1) mengaktifkan mahasiswa dalam belajar; 2) membantu mahasiswa mengembangkan dan menemukan konsep berdasarkan pendeskripsian hasil pengamatan dan data yang diperoleh dalam eksperimen; 3) melatih mahasiswa menemukan konsep melalui pendekatan keterampilan proses; 4) membantu dosen menyusun/merencanakan kegiatan pembelajaran yang tepat berdasarkan karakteristik mahasiswa; dan 5) membantu dosen menyiapkan secara tepat dan cepat kegiatan pembelajaran, sehingga LKM yang telah dibuat dapat digunakan pada tahun ajaran berikutnya.

Inkuiri adalah sebuah pendekatan dalam belajar dimana mahasiswa menemukan dan menggunakan berbagai sumber informasi dan ide-ide untuk meningkatkan pemahaman mereka tentang topik, atau masalah yang diberikan oleh dosen (Kuhlthau et al., 2007), suatu pola pembelajaran untuk membantu mahasiswa belajar merumuskan dan menguji pendapatnya sendiri serta memiliki kesadaran akan kemampuannya (Joyce et al.,2011), dan suatu proses untuk memperoleh informasi dengan melakukan observasi dan atau eksperimen untuk mencari jawaban atau memecahkan masalah terhadap pertanyaan atau rumusan masalah dengan menggunakan berpikir kritis dan logis.

Pembelajaran berbasis inkuiri terbimbing menggunakan masalah sebagai "trigger" untuk belajar. Masalah yang digunakan sebagai "trigger" dalam LKM ini dikemas dalam bentuk wacana. Salah satu catatan penting dari penilaian ahli perangkat pembelajaran, ahli materi, dan praktisi pengajar di lapangan adalah ketepatan dalam pemilihan masalah yang sesuai dengan pembelajaran berbasis inkuiri terbimbing.

Model pembelajaran inkuiri terbimbing menurut Paidi (2008) merupakan salah satu model pembelajaran yang penting dalam membangun paradigma pembelajaran konstruktivistik yang menekankan pada keaktifan belajar peserta didik. Pentingnya keaktifan peserta didik dalam pembelajaran seperti dinyatakan Minstrell dan Krauss (2005) bahwa belajar merupakan suatu proses aktif. Tugas dosen dalam proses pembelajaran dengan model inkuiri terbimbing adalah memberikan kesempatan pada mahasiswa untuk menggunakan seluruh inderanya dalam memperoleh pengalaman belajar dan membantu memaksimalkan pengalaman belajar, salah satunya melalui pemberian pertanyaan pengiring. Pertanyaan dari dosen dapat mewakili pertanyaan mahasiswa kepada diri mereka sendiri ketika melaksanakan inkuiri secara personal.

Pembelajaran berbasis inkuiri terbimbing berdasarkan hasil penelitian Strom (2012) dapat mengembangkan keterampilan proses sains dan pemahaman konsep sains mahasiswa. Hal ini sesuai dengan konsep pembelajaran inkuiri 
menurut Callahan, et al., (1991) yang menyatakan bahwa inkuiri merupakan model pembelajaran yang dapat dikatakan sebagai suatu siklus yang dapat dimulai dari tahap manapun. Siklus tersebut terdiri dari: 1) proses membangun ide; 2) proses penggunaan ide; 3 ) proses mencari data; dan 4) proses organisasi data.

Perkuliahan haruslah dapat meningkatkan kemampuan keterampilan proses sains mahasiswa melalui kegiatan di laboratorium sehingga mahasiswa dapat mengkaji dan membangun pengetahuan sendiri. Perkuliahan yang efektif adalah perkuliahan yang tidak hanya membahas tentang materi perkuliahan sesuai dengan rincian pada Silabus dan SAP, tetapi juga harus proses pembelajaran keterampilan proses sains. Dalam hal ini mahasiswa mestinya secara sadar terlibat dalam suatu perkuliahan yang menyebabkan terjadinya peningkatan keterampilan proses sains.

White (1997) dalam Paidi (2008) menjelaskan bahwa masalah kompleks atau ill structured diperlukan untuk melatih kemampuan peserta didik mengenal masalah autentik dan menemukan alternatif-alternatif solusinya. Permasalahan kompleks memerlukan analisis, upaya kooperatif, serta pemikiran dari berbagai sudut pandang untuk dapat mengenal dan memecahkannya dengan baik. Pembelajaran yang didasarkan pada ill structured menempatkan peserta didik untuk bekerja secara berkelompok secara kolabortif untuk mengidentifikasi halhal yang mereka perlukan untuk belajar guna memecahkan masalah, mengarahkan belajar mandiri, mengaplikasikan pengetahuan baru mereka untuk permasalahan itu, serta merefleksi apa yang telah mereka pelajari dan keefektifan strategi yang telah mereka gunakan.

Komponen-komponen dalam LKM diharapkan dapat menciptakan suasana belajar yang berlangsung secara interaktif, inspiratif, menyenangkan, menantang, memotivasi mahasiswa untuk berpartisipasi aktif, dan memberikan ruang yang cukup bagi prakarsa, kreativitas, dan kemandirian sesuai dengan bakat, minat, dan perkembangan fisik serta psikologi mahasiswa. LKM hasil pengembangan juga menjadi dokumen kurikulum yang berkualitas, sebab telah melewati tahap validasi dan uji coba, sehingga layak digunakan oleh mahasiswa.

Berdasarkan uraian tentang kajian dari produk pengembangan berupa LKM, secara umum menunjukkan bahwa LKM yang dikembangkan memiliki kelebihan karena bermanfaat sebagai panduan bagi mahasiswa belajar mandiri untuk memahami bahan kajian yang akan dipelajari. LKM yang dikembangkan disesuaikandengan model pembelajaran berbasis inkuiri terbimbing sehingga dapat mengarahkan mahasiswa untuk menemukan atau menerapkan sendiri ideidenya. LKM juga telah melewati tahap validasi oleh validator ahli yang menyatakan bahwa LKM termasuk dalam kategori baik sehingga layak untuk digunakan dalam pembelajaran. Kelemahan LKM yang dikembangkan adalah percobaan yang dilakukan oleh mahasiswa hanya satu macam untuk setiap materi pokok, oleh karena itu perlu mengembangkan percobaan lain yang masih berada dalam lingkup materi pokok yang sama.

\section{KESIMPULAN}

Berdasarkan hasil analisis dan pembahasan dari hasil penelitian pengembangan yang telah dilakukan, dapat disimpulkan sebagai berikut. 1) LKM yang dikembangkan termasuk dalam kategori baik dan memenuhi kriteria 
kelayakan untuk dilaksanakan dalam pembelajaran di kelas. 2) Hasil uji coba utama menunjukkan keterlaksanaan pembelajaran dan hasil LKM yang dikerjakan oleh mahasiswa termasuk dalam kategori baik.

\section{DAFTAR PUSTAKA}

Apriliyana, U., Fitrihidayati H., dan Rahadjo. 2012. Pengembangan Perangkat Pembelajaran Berbasis Inkuri pada Materi Pencemaran Lingkungan dalam Upaya Melatih Keterampilan Berpikir Kritis Siswa Kelas X SMA. Jurnal BioEdu, (Online), 1 (3) Desember 2012: 39-44, (http://ejournal. unesa.ac.id/index. php/bioedu), diakses 03 Mei 2014.

Arifin, Z. 2009. Evaluasi Pembelajaran (Prinsip, Teknik, Prosedur). Bandung: Remaja Rosdakarya.

Arikunto, S. 1998. Prosedur Penelitian Suatu Pendekatan Praktik. Jakarta: Rineka Cipta.

Astuti, Y. dan Setiawan, B. 2013. Pengembangan Lembar Kerja Siswa (LKS) Berbasis Pendekatan Inkuiri Terbimbing dalam Pembelajaran Kooperatif pada Materi Kalor. Jurnal Pendidikan IPA Indonesia. 2 (1) (2013). 88-92.

Callahan, J.F., Leonard, H.C., Kellough, R.D. 1992. Teaching in the Middle and Secondary Schools $4^{\text {th }}$. USA: Maccmillan Publishing Company.

Depdiknas. 2008a. Panduan Umum Pengembangan Bahan Ajar. Jakarta: Direktorat Jenderal Manajemen Pendidikan Dasar dan Menengah. (Online), (http://akhmadsudrajat.files. wordpress.com/2008/09/panduanpengembangan-bahanajar.pdf), diakses 19 Juni 2014.

Joyce, B., Marsha W., dan Emily C. 2011. Models of Teaching. Yogyakarta: Pustaka Belajar.

Kubicek, P. John. 2005. Inquiry-Based Learning, the Nature of Science, and Computer Technology: New Possibilities in Science Education. Canadian Journal of Learning and Technology (Online), 31(1):1-5, (http://www.cjlt.ca/index.php/cjlt/ article/view/149/142), diakses 19 Juni 2014.

Kuhlthau, C. C., Leslie K. M., dan Ann K. C. Guided Inquiry. Learning in the 21 st Century. London: Libraries Unlimited.

Mustachfidoh, Swasta, I. B. J., dan Widiyanti, N. L. P. M. 2013. Pengaruh Model Pembelajaran Inkuiri terhadap Prestasi Belajar Biologi ditinjau dari Inteligensi Siswa SMA Negeri 1 SRONO. e-Journal Program Pascasarjana Universitas Pendidikan Ganesha Program Studi Pendidikan IPA (Online), 3 (1): 2013, (http://pasca.undiksha.ac.id/e-journal/index.php/jurnal_ipa/ article/view/542), diakses 19 Februari 2014.

Minstrell, J., P, Krauss. 2005. Guided Inquiry in the Science Classroom. Dalam Suzanne M. Donovan dan John D. Bransford (Ed.), How Students Learn: Science in the Classroom (hlm. 475-513). Washington: National Academy of Sciences. 
Paidi. 2008. Peningkatan Scientific Skill Siswa Melalui Implementasi Metode Guided Inquiry pada Pembelajaran Biologi di SMAN 1 Sleman. (Online), (http://www.e-prints.uny.ac.id), diakses 15 Juli 2014.

Prastowo A. 2011. Panduan Kreatif Membuat Bahan Ajar Inovatif. Yogyakarta: Diva Press.

Rahmi, Villia Anggraini, dan Melisa. 2014. Pengembangan Lembar Kerja Mahasiswa Berbasis Problem Based Learning pada Perkuliahan Persamaan Difrensial Biasa. Prosiding Seminar Nasional Sains dan Pendidikan Sains IX, Fakultas Sains dan Matematika UKSW. Salatiga, 21 Juni 2014, Vol 5, No. 1, ISSN: 2087-0922.

Riduwan. 2005. Skala Pengukuran Variabel-variabel Penelitian. Bandung: Alfabeta.

Rohman, M. dan Amri, S. 2013. Strategi dan Desain Pengembangan Sistem Pembelajaran. Jakarta: Prestasi Pustakarya.

Strom, R.K. 2012. Using Guided Inquiry to Improve Process Skills and Content Knowledge in Primary Science. Montana: Montana State University.

Tryanasari, D. 2011. Penggunaan Lembar Kerja Mahasiswa Terbimbing Berbasis Inquiry Pada Mata Kuliah Peningkatan Keterampilan Berbahasa Indonesia (PKBI) Untuk Mengembangkan Karakter Mahasiswa PGSD IKIP PGRI Madiun. Jurnal Premiere Educandum (Online), 1 (2): 2011, (http://www.

ikippgrimadiun.ac.id/ejournal/sites/default/files/2_Dewi_Lembar KerjaInquiry. pdf), diakses 15 April 2014.

Winarno. 2009. Teknik Evaluasi Multimedia Pembelajaran. Yogyakarta: Genius Prima Media.

Yasmi, E dan Erviyenni. 2016. Pengembangan Lembar Kerja Mahasiswa (LKM) Berbasis Kontekstual pada Mata Kuliah Kimia Organik. (Online), (http://download.portalgaruda.org/article.php?article=439860\&val=9306\& title=PENGEMBANGAN\%20LEMBAR\%20KERJA\%20MAHASISWA $\% 20($ LKM)\%20BERBASIS\%20KONTEKSTUAL\%20PADA\%20MATA \%20KULIAH\%20KIMIA\%20ANORGANIK), diakses 03 November 2016.

Yonata, B. 2009. Pengembangan Perangjat Pembelajaran Kimia Berbantuan Internet dengan Setting Multi Model. (Online), Vol. 2 (1) (http://file.upi.edu/Direktori/

JURNAL/PENDIDIKAN_TIK/Jurnal_Pend_TIK_Vol_2_No_1/PENGEM BANGAN_PERANGKAT_PEMBELAJARAN_KIMIA_BERBANTUAN _INTERNET_DENGAN_SETING_MULTI_MODEL.pdf), diakses 25 Februari 2014. 